OPEN ACCESS

Edited by:

Carlos Alonso Alvarez, Consejo Superior de Investigaciones Científicas (CSIC), Spain

Reviewed by: Jose A. Masero,

University of Extremadura, Spain Oded Berger-Tal, Ben-Gurion University of the Negev

Israel

${ }^{*}$ Correspondence: Adolfo Cordero-Rivera adolfo.cordero@uvigo.es

Specialty section:

This article was submitted to Behavioral and Evolutionary Ecology,

a section of the journal

Frontiers in Ecology and Evolution

Received: 27 December 2016 Accepted: 06 February 2017 Published: 17 February 2017

Citation: Cordero-Rivera A (2017) Behavioral Diversity (Ethodiversity): A Neglected Level in the Study of Biodiversity. Front. Ecol. Evol. 5:7. doi: 10.3389/fevo.2017.00007

\section{Behavioral Diversity (Ethodiversity): A Neglected Level in the Study of Biodiversity}

\author{
Adolfo Cordero-Rivera * \\ ECOEVO Lab, Universidade de Vigo, EUE Forestal, Pontevedra, Spain
}

The concept of biodiversity embraces a multifaceted and hierarchical analysis of the complexity of life, with implications in many areas of science, philosophy, ethics, politics, and even religion. Three levels are included in the commonly accepted definitions: genetical, species, and ecosystem diversity, going from the intraspecific level to the landscape. Here, I argue that a fourth level, never included in biodiversity studies, is of prominent relevance: ethological diversity or "ethodiversity." There is a growing number of studies describing alternative behaviors, behavioral plasticity, learning, and even personality, as characteristics of animal populations or individuals. Ethodiversity is also relevant in unraveling cryptic biodiversity, such as species that differ in their behavior but are otherwise undistinguishable. Maintaining ethodiversity is therefore essential in conservation, and cannot be achieved simply by focusing on genetic diversity. Behavior has profound ecological consequences, particularly in species interactions, and is a crucial element in the adaptability of animals to new environments. Ethodiversity is important at the intraspecific, inter-population, and species level and has practical relevance in several fields, like captive breeding, eco-novelty, and popular science. Finally, I expect ethodiversity to show a latitudinal cline, with more diverse and elaborate behaviors per species in the tropical regions, given the increase in interactions near the equator.

Keywords: biological diversity, ethodiversity, behavioral diversity, behavior, concept, cultural significant units, Ethology

\section{INTRODUCTION}

The variety of life has been a fascinating theme for human curiosity, probably since our emergence as a species, as is clear from the prehistoric art. We are part of the diversity of life, and we depend on it for all our needs. This self-evident statement encompasses much more complex ideas that seem at first sight (Takacs, 1996). During the second half of the twentieth century, the study of biological diversity was mainly an ecological endeavor, with the species as the basic unit of biotic interactions. Many indexes were proposed to grasp species diversity inside and among ecosystems (Magurran, 1988). The concepts of alpha, beta, and gamma diversity refer in fact to species diversity (Whittaker, 1972), although they can be easily expanded to other levels of biological diversity.

The word "biodiversity" appeared in the scientific literature as the title of a book edited by Wilson and Peter (1988). Walter G. Rosen, who proposed the term, says "It was easy to do: all you do is take the 'logical' out of 'biological"' and ironizes: "To take the logical out of something that's supposed to be science is a bit of a contradiction in terms, right?" (Takacs, 1996). The term 
was coined at the interplay between science and politics (Maclaurin and Sterelny, 2008), with the clear purpose to contribute to biodiversity conservation (Takacs, 1996). In this sense, the word was instrumental and readily adopted by important organizations with a great social and political impact, like WWF (Adams, 2004).

Given the widespread use and the success of the concept of biodiversity, it is surprising that behavioral diversity is rarely considered in the literature on biodiversity. Caro and Sherman (2012) explicitly argued to consider behavioral diversity as part of biodiversity, although they restricted their definition of behavioral diversity to the population and species level. Interpopulation divergences in behavior have been considered part of biodiversity (Stone et al., 2012), but it is clear that other levels are also of relevance: "personality differences are an important, yet up to now largely neglected, dimension of biodiversity" (Wolf and Weissing, 2012). The aims of this essay are to highlight the importance of behavioral diversification in the origin and maintenance of biodiversity at all its levels, and the implications of behavioral diversity in Conservation Biology. To effectively preserve biodiversity we need an explicit assessment of all its components, which means overcoming counting genes, species or ecosystems. Ethological components underpin many aspects of the mechanisms that result in species formation and thus in the generation of biodiversity. I propose the term "ethodiversity" for this concept.

\section{BIODIVERSITY AS A META-CONCEPT}

Takacs (1996) interviewed a group of 23 prominent biologists in 1992, asking them for a definition of biodiversity and obtained an array of different answers. Van Dyke (2008) lists 14 definitions compiled from the literature. Entire books are dedicated to defining and describing this concept (Lévêque and Mounolou, 2003; Gaston and Spicer, 2004; Maclaurin and Sterelny, 2008). Even if these definitions are as diverse as the concept that they try to delineate, most share the idea that biodiversity is a hierarchical concept with three main levels: intraspecific genetic variability, differences between species and between ecosystems.

Ford (2000) classifies scientific concepts into three categories: natural, functional, and integrative. Natural concepts refer to phenomena that can be easily described and grasped by our senses, like a tree or a stone. Functional concepts describe the properties of natural concepts or relate two or more natural concepts. Predatory behavior is an example of a functional concept. Integrative concepts are theoretical constructions about nature, based on the relationship between natural and functional concepts, and usually refer to a hierarchical system. The forest is an example of an integrative concept (Cordero-Rivera, 2012).

The concept of biodiversity is clearly a combination of many points of view to describe the complexity of life. It encompasses ecological, genetic, and taxonomic hierarchies, including social, philosophical, ethical, and religious aspects. Therefore, biodiversity is a meta-concept, an integration of several already integrative concepts. Consider the usual definitions that include genetic and ecological diversity. These belong to two partially overlapping hierarchies, from genes within populations, to species in communities, to ecosystems in different biomes. Other aspects of biodiversity, seldom addressed in biodiversity inventories include phylogenetic diversity, diversity of ecological functions (functional diversity), and ethological (behavioral) diversity. Ethodiversity is defined as the variability of behavioral traits in the biological hierarchy, including the individual level (for example personality), the population level (for instance alternative reproductive strategies), and the ecosystem level (like contrasting behavioral patterns between species). If behavior is defined as the response of biological entities to the environment (see Levitis et al., 2009, for a discussion of the concept), this term can also be applied not only to individuals or species, but also to communities. There is therefore also an ethological hierarchy embedded in the concept of biodiversity.

\section{ETHODIVERSITY IS NOT EQUIVALENT TO FUNCTIONAL DIVERSITY}

Species diversity alone is not a good descriptor of community complexity. This has led to the use of functional diversity as a measure of species interactions and relative importance in the community, because this property is expected to influence ecosystem stability, productivity, dynamics, nutrient cycling, and so on (Tilman et al., 2014). Species perform different functions in a community when they use contrasting ways to obtain their food or resources, even if they belong to the same trophic level, like plants able to fix atmospheric nitrogen and those unable to perform this task. For this reason, studies of functional diversity select only a few traits, those that are considered of relevance for community structure (Petchey and Gaston, 2002), and usually ignore behavior or the diversity of processes in which these traits are functional.

For example, consider the spiders of the family Deinopidae (Figure 1). They are functionally equivalent to other orb-web spiders, but they use a unique and specialized way of capturing their prey: they construct a web and maintain it open with their legs, instead of constructing a web fixed to the substratum. Then, sit and wait and use a backward strike to capture aerial prey and a forward strike to capture walking prey (Getty and Coyle, 1996). Their presence in a community increases ethological diversity of the spider functional group, but does not affect functional diversity.

The interactions between plants and their pollinators is a system where functional diversity has been intensively studied (Fenster et al., 2004). The extinction of pollinators has profound consequences in the community, even with cascading effects between birds and plants (Anderson et al., 2011). Insect pollinators have been shown to belong to several functional groups, reflecting somehow their taxonomic identity (Fenster et al., 2004). Plants are considered to select between alternative pollinator functional groups due to the form of the flower. This has led to the repeated "discovery" by pollinators of the robbery strategy, i.e., obtaining nectar through a hole made in the corolla. The ecological consequences of such behavior for the plant might be negative, because robbers get the prize without contributing to pollination. Several species of birds, bees, and ants have been 


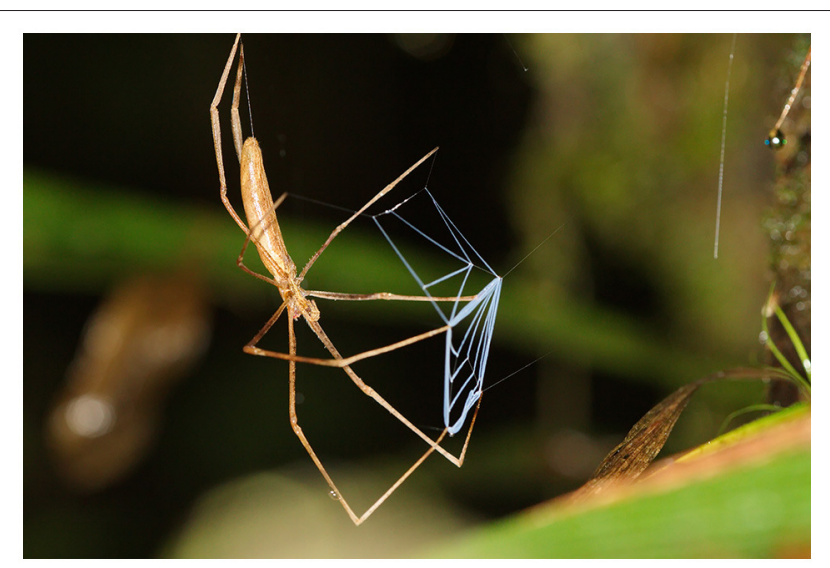

FIGURE 1 | Ethological diversity is not equivalent to functional diversity. The spiders of the genus Deinopus (family Deinopidae) are functionally equivalent to orb-web spiders, but they do not attach the web to the substrate, maintaining it between the legs. They use a backward strike to capture aerial prey and a forward strike to capture walking prey, and are a clear example of ethological diversification in a functional group. Picture taken at Rara Avis reserve (Costa Rica) by the author.

found acting as nectar robbers, and irrespective of their impacts on plants as cheaters or mutualists (Irwin et al., 2010), they contribute to the ethological diversity of pollinator functional groups, without increasing functional diversity.

\section{SOURCES OF ETHODIVERSITY}

In classic ethology, the first step to study animal behavior was the construction of an "ethogram," considered the complete description of behavioral repertory of an animal (Alcock, 2003). This approach is rarely used recently, probably because it is considered too descriptive, and very difficult to standardize (Schleidt et al., 1984).

Recent research on individual variation in other fields of Ecology has highlighted the relevance of variation across individuals in community ecology (Bolnick et al., 2011). Ethologists and Behavioral Ecologists have described a surprising variety of behaviors, and found many ecological correlates that allow predicting behavioral patterns (Alcock, 1993). Many studies have found high phenotypic plasticity in behavior (Cordero Rivera and Andrés, 2002), alternative strategies in males (Cade, 1980) and females (Sirot et al., 2003), or animal personalities (Briffa and Weiss, 2010). Animal culture is relevant in conservation planning of small populations (Ryan, 2006). So, how is this variation maintained?

Given that behavior is a phenotypic trait, ethological diversity is maintained by the same mechanisms that maintain genetic diversity, and is also a by-product of ecological (ecosystem) diversity. However, some components of behavior escape this framework, like learning and cultural transmission of behaviors. On the other side, ethological differences may contribute or even predate speciation, and be the main process generating cryptic species, like crickets or birds only differentiable by male songs (Irwin et al., 2001; Mendelson and Shaw, 2005).
Whenever the environment is heterogeneous (in time or space) natural selection can be a strong force maintaining diversity, by means of the mechanisms of local adaptation. This frequently generates ethodiversity. American dippers constitute an example of ethodiversity in migratory strategies: some individuals are resident but others are altitudinal migrants (Gillis et al., 2008). Both strategies seem almost fixed, because only $2 \%$ of the monitored individuals switched strategy along their lives, but the individual's strategy was not necessarily that of its parents. Fire salamanders (Salamandra salamandra) are nocturnal animals, active under humid mild climate (Figure 2a). Nevertheless, in two islands separated only by $12 \mathrm{~km}$ in the coast of NW Spain, they show contrasting behaviors, being nocturnal in one island but mainly diurnal in the other (Figure 2b), perhaps due to divergent predation regimes (Velo-Antón and CorderoRivera, 2011). In the same region, freshwater snakes (Natrix maura) go to seashore pools to capture marine fish (Galán, 2012), a behavior which has clear ecological consequences, but is rarely reported for the species. This last example might be due to learning (Pearce, 2008). Ethological innovations due to learning processes allow animals to change their response to ecological challenges very fast, unlike adaptation, which needs changes in gene pools (Supplementary Video 1; Supporting information; see also Rubenstein, 2016). Therefore, the usual intraspecific quantification of biodiversity, based on allelic diversity, does not capture the essence of intraspecific ethodiversity, particularly learning abilities, personalities, and culture.

\section{MEASURING ETHODIVERSITY}

As I discussed above, ethodiversity can be found at different levels of the biological hierarchy. It is clearly found at the individual level (plasticity, learning, personality). The existence of personalities in wild animals is an emergent topic of study (Briffa and Weiss, 2010), even in wild populations (Drent et al., 2003). This bridges with the newly revival of interest in the ecology of individual variation mentioned above (Bolnick et al., 2011).

As is typical of integrative concepts we cannot measure global ethodiversity, but only some surrogates (Ford, 2000). A further complication is the fact that behavioral variables are likely to be more plastic than other characters, and therefore scoring behavioral diversity might be limited by the ecological settings where behavior is observed. Currently several approaches have been developed to quantify genetic diversity at the individual and population level. These approaches tabulate genes and individuals, so that the frequency of each allele can be calculated from a particular sample, and diversity can then be estimated, and indexes of differentiation are derived, like F $_{\text {ST }}$-values (Nei, 1986).

In the case of ethodiversity, similar approaches may be fruitful. As an illustration Table S1 (Supporting information) shows a summary of reproductive behaviors in the Odonata, and alternative behaviors are listed, with examples of species for each alternative. To quantify ethodiversity in a group, for instance at the species level, one needs to study the reproductive behavior of a sample of individuals and record the frequency 

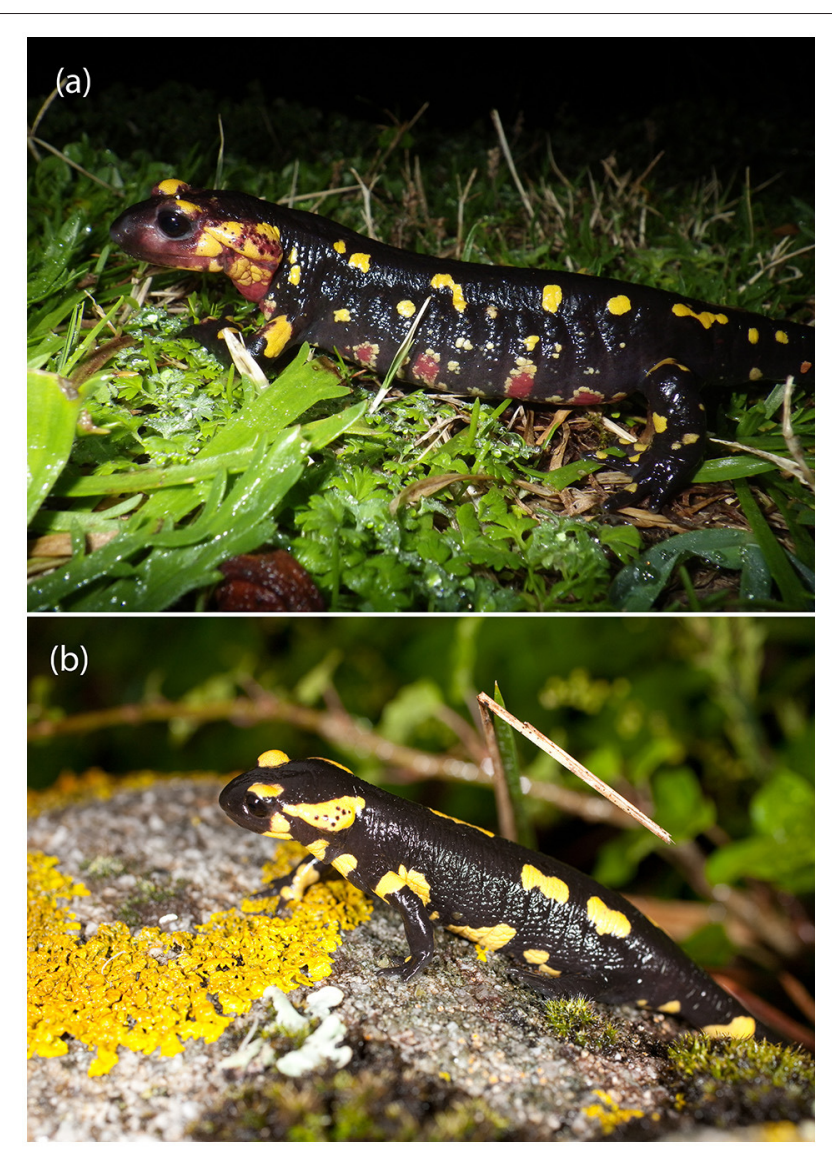

FIGURE 2 | Isolation and ecological heterogeneity contribute to ethodiversity in fire salamanders. In the island of Ons, salamanders show the typical nocturnal activity (a, an individual in the characteristic predatory position photographed by night). In the island of San Martiño (Cíes), at only 12 $\mathrm{km}$, salamanders are diurnal (b, picture taken at 11:21 A.M.). Pictures by the author.

of each alternative behavior. Then, an index of diversity can be calculated. This would be analogous to instraspecific genetic variability. Similarly, studying and quantifying behavioral patterns in a community would allow a description of ethodiversity at that level. Careful consideration should be given to sampling effort to get a representative sample of behavioral diversity. Even the "simple" species diversity is extremely difficult to estimate from samples, particularly in species-rich communities (Gotelli and Colwell, 2001). Many behaviors are expected to be highly sensitive to local ecological conditions (Caro and Sherman, 2012), and therefore be detected only in some populations, or under specific ecological circumstances.

In some situations ethological diversity will be closely linked to functional diversity, for instance when traits used to define functional groups are behavioral attributes. The measurement of functional diversity is challenging, as illustrates the debate about which index is more appropriate (Podani and Schmera, 1998; Petchey and Gaston, 2002). Because functional analyses aim at identifying assemblages of similar species (guilds, functional groups) the functional diversity approach (Petchey and Gaston,
2002), based on dendrograms and a calculation of distances between species, is not useful to quantify ethodiversity, because it does not aim at grouping species. Nevertheless, studying ethodiversity in a phylogeny is a promising research line.

\section{PATTERNS IN ETHODIVERSITY}

There is still little information about ethodiversity available to characterize patterns. However, some predictable patterns are expected. One is related to the latitudinal gradient in biodiversity (Gaston, 2000). Ethodiversity is expected to be related to biological complexity, and to be maximum in tropical areas. An increase in species richness will obviously be positively related to ethodiversity, simply because more species also mean, generally, greater phylogenetic diversity. However, the increase in ß-diversity (e.g., morphological or genetic) in the tropics might also enhance the diversity of ethological repertories per species and its variation across space. Therefore, the expectation is that the "average species" will be more ethodiverse in tropical regions. Human languages, a clear example of ethodiversity, are more diverse precisely at biodiversity hot-spots (Gorenflo et al., 2012). A study of song repertories in birds (Laiolo and Jovani, 2007) could be useful to test this idea.

Sexual selection is a powerful force in evolution, which has produced and maintains many of the most extraordinary behaviors and morphological adaptations exhibited by animals during mating (Eberhard, 1985; Andersson, 1994). I predict that ethodiversity will be positively correlated with the intensity of sexual selection. The birds of paradise unusual behavior (Laman and Scholes, 2012) is probably the most clear example of this.

\section{BEHAVIOR AND CONSERVATION, THE PRACTICAL RELEVANCE OF ETHODIVERSITY}

Animal behavior is certainly a relevant issue in conservation (Cassini, 1999; MacDonald, 2013). Several authors have reviewed this topic (Curio, 1996; Caro, 1998; Gostling and Sutherland, 2000; Moore et al., 2008; Berger-Tal and Saltz, 2016), and therefore I will not discuss it further. I will nevertheless highlight the fact that captive breeding programs, particularly of predatory animals, cannot be successful without an ethological perspective, as the story of black-footed ferret recovery plan clearly illustrates (Vargas et al., 1999). Maintaining ethological diversity (and plasticity) is also crucial for the viability of reintroduced animals (MacDonald, 2013), for the management of small populations (Ryan, 2006) and in animal welfare (Grandin, 2003).

Ethodiversity is important in another field: popular science. The social impact of science is one of the multiple approaches to study its relevance, and animal behavior is clearly the most popular and fascinating topic for most of the television programs addressed to the great public. The interest of human society on "what animals do" is an opportunity for conservation, and using some animals and their diversity of behaviors might function as a 
surrogate to protect their habitats (Laiolo and Jovani, 2007), in a similar way as the concept of "umbrella species" in Conservation Biology (Roberge and Aangelstam, 2004).

Ethodiversity is expected to be of great relevance in some ecological settings, one of which is related to the concept of naïveté and evolution on islands. I have already mentioned the example of the diurnal salamanders, which illustrates the fact that islands are evolutionary laboratories. This has also deep consequences on biodiversity conservation. Extinctions have occurred at higher rates in islands than in continents, mostly due to the introduction of exotic predators and competitors (Nogales et al., 2004). Reduced behavioral diversity, and particularly the lack of strategies to cope with introduced predators, is behind the rapid extinction of many large flightless island arthropods, illustrated by the noteworthy example of Lord Howe "treelobster" Dryococelus australis rediscovery (Priddel et al., 2003). The naïveté of many animals, that do not recognize humans as predators, is also behind the rapid extinction of many island vertebrates (e.g., Holdaway and Jacomb, 2000). Behavioral diversity was suggested to be a relevant part of biological diversity precisely studying how domestic cats affected the behavior of lava lizards in the Galapagos (Stone et al., 2012). Super specialist predators, unable to change their behavior and feed on alternative prey, are also at high risk of extinction (e.g., Ferrer and Negro, 2004).

Conservation implications of the concept of ethodiversity might be also apparent at the ecosystem level. The consequences of species extinctions for ecological networks are at the center of applied ecology research, with much debate about the possible species redundancy and how this affects ecosystem function (e.g., Schwartz et al., 2000). Even if not explicitly recognized, much functional diversity is in fact ethological diversity: species are not only gene pools and a set of ecological attributes, they are divergent ethological entities. The loss of ecological interactions (Valiente-Banuet et al., 2015) is in many cases a loss of ethological diversity, which impairs ecological networks. For instance, human-induced defaunation affects large species more intensively, and this has cascading effects on plants when animals

\section{REFERENCES}

Adams, W. M. (2004). Against Extinction. The Story of Conservation. London: Earthscan.

Alcock, J. (1993). Animal Behavior, 5th Edn. Sunderland, MA: Sinauer.

Alcock, J. (2003). A textbook history of animal behaviour. Anim. Behav. 65, 3-10. doi: 10.1006/anbe.2002.2044

Anderson, S. H., Kelly, D., Ladley, J. L. J., Molloy, S., and Terry, J. (2011). Cascading effects of bird functional extinction reduce pollination and plant density. Science 331, 1068-1071. doi: 10.1126/science.11 99092

Andersson, M. (1994). Sexual Selection. Princeton, NJ: Princeton University Press.

Angeloni, L., Schlaepfer, M. A., Lawler, S. J., and Crooks, K. R. (2008). A reassessment of the interface between conservation and behaviour. Anim. Behav. 75, 731-737. doi: 10.1016/j.anbehav.2007.08.007

Berger-Tal, O., and Saltz, D. (2016). Conservation Behavior: Applying Behavioral Ecology to Wildlife Conservation and Management. New York, NY: Cambridge University Press. are the main seed dispersals (Pérez-Méndez et al., 2016), which is a behavioral attribute.

Despite the repeated claims advocating the relevance of animal behavior as basic for conservation science, the great potential of behavioral research to improve conservation practices is still far from being fulfilled (Angeloni et al., 2008). Future studies on biodiversity conservation must give more attention to animal behavior (or even plant behavior, van Loon, 2016). I hope that the term "ethodiversity," due to its parallelism with "biodiversity," might contribute to its acceptance by conservation biologists and therefore stimulate research on the conservation of behavior (Caro and Sherman, 2012).

\section{AUTHOR CONTRIBUTIONS}

The author confirms being the sole contributor of this work and approved it for publication.

\section{ACKNOWLEDGMENTS}

The ideas presented here were developed during a sabbatical leave to study the reproductive behavior of two "mirabilis" damselflies, Hemiphlebia mirabilis in Victoria, Australia and Pseudolestes mirabilis in Hainan, China. Many thanks to Ian Endersby, Rheiner Richter, Richard Rowe, and Haomiao Zhang for their help during these field-work periods. I am much grateful to Pedro Jordano, David J. Thompson, Alex Córdoba-Aguilar, and Robby Stoks for their comments on previous versions of the manuscript. Funding was provided by grants from the Spanish Ministry with competences in Science, including FEDER funds (projects CGL2011-22629 and CGL201453140-P).

\section{SUPPLEMENTARY MATERIAL}

The Supplementary Material for this article can be found online at: http://journal.frontiersin.org/article/10.3389/fevo. 2017.00007/full\#supplementary-material

Bolnick, D. I., Amarasekare, P., Araújo, M. S., Bürger, R., Levine, J. M., Novak, M., et al. (2011). Why intraspecific trait variation matters in community ecology. Trends Ecol. Evol. 26, 183-192. doi: 10.1016/j.tree.2011. 01.009

Briffa, M., and Weiss, A. (2010). Animal personality. Curr. Biol. 20, R912-R914. doi: 10.1016/j.cub.2010.09.019

Cade, W. H. (1980). Alternative male reproductive behaviors. Florida Entomol. 63, 30-45. doi: 10.2307/3494654

Caro, T. (1998). Behavioral Ecology and Conservation Biology. Oxford: Oxford University Press.

Caro, T., and Sherman, P. W. (2012). Vanishing behaviors. Conserv. Lett. 5, 159-166. doi: 10.1111/j.1755-263X.2012.00224.x

Cassini, M. H. (1999). Importancia de la Etología en la Conservación. Etología 7 , 69-75.

Cordero Rivera, A., and Andrés, J. A. (2002). Male coercion and convenience polyandry in a Calopterygid damselfly (Odonata). J. Insect Sci. 2, 14. doi: 10.1673/031.002.1401

Cordero-Rivera, A. (2012). Bosques e plantacións forestais: dous ecosistemas claramente diferentes. Recur. Rurais Ser. Cursos 6, 7-17. 
Curio, E. (1996). Conservation needs ethology. Trends Ecol. Evol. 11, 260-263. doi: 10.1016/0169-5347(96)20046-1

Drent, P. J., van Oers, K., and van Noordwijk, A. J. (2003). Realized heritability of personalities in the great tit (Parus major). Proc. R. Soc. B Biol. Sci. 270, 45-51. doi: $10.1098 / \mathrm{rspb} .2002 .2168$

Eberhard, W. G. (1985). Sexual Selection and Animal Genitalia. Cambridge, MA: Harvard University Press.

Fenster, C. B., Armbruster, W. S., Wilson, P., Dudash, M. R., and Thompson, J. D. (2004). Pollination syndromes and floral specialization. Annu. Rev. Ecol. Syst. 35, 375-403. doi: 10.1146/annurev.ecolsys.34.011802.132347

Ferrer, M., and Negro, J. J. (2004). The near extinction of two large European predators: super specialists pay a price. Conserv. Biol. 18, 344-349. doi: 10.1111/j.1523-1739.2004.00096.x

Ford, E. D. (2000). Scientific Method for Ecological Research. Cambridge: Cambridge University Press.

Galán, P. (2012). Natrix maura en el medio marino de las Islas Atlánticas de Galicia. Boletín la Asoc. Herpetol. Española 23, 38-43.

Gaston, K. J. (2000). Global patterns in biodiversity. Nature 405, 220-227. doi: $10.1038 / 35012228$

Gaston, K. J., and Spicer, J. I. (2004). Biodiversity. An Introduction, 2nd Edn. Oxford: Blackwell Publishing.

Getty, R. M., and Coyle, F. A. (1996). Observations on prey capture and antipredator behaviors of ogre-faced spiders (Deinopis) in Southern Costa Rica (Araneae, Deinopidae). J. Arachnol. 24, 93-100.

Gillis, E. A., Green, D. J., Middleton, H. A., and Morrissey, C. A. (2008). Life history correlates of alternative migratory strategies in American Dippers. Ecology 89, 1687-1695. doi: 10.1890/07-1122.1

Gorenflo, L. J., Romaine, S., Mittermeier, R. A., and Walker-Painemilla, K. (2012). Co-occurrence of linguistic and biological diversity in biodiversity hotspots and high biodiversity wilderness areas. Proc. Natl. Acad. Sci. U.S.A. 109, 8032-8037. doi: $10.1073 /$ pnas.1117511109

Gostling, L. M., and Sutherland, W. J. (2000). Behaviour and Conservation. Cambridge: Cambridge University Press.

Gotelli, N. J., and Colwell, R. K. (2001). Quantifying biodiversity: Procedures and pitfalls in the measurement and comparison of species richness. Ecol. Lett. 4, 379-391. doi: 10.1046/j.1461-0248.2001.00230.x

Grandin, T. (2003). Transferring results of behavioral research to industry to improve animal welfare on the farm, ranch and the slaughter plant. Appl. Anim. Behav. Sci. 81, 215-228. doi: 10.1016/S0168-1591(02)0 0282-4

Holdaway, R. N., and Jacomb, C. (2000). Rapid extinction of the Moas (Aves: Dinornithiformes): model, test, and implications. Science 287, 2250-2254. doi: 10.1126/science.287.5461.2250

Irwin, D. E., Alström, P., Olsson, U., and Benowitz-Fredericks, Z. M. (2001). Cryptic species in the genus Phylloscopus (Old World leaf warblers). Ibis 143, 233-247. doi: 10.1111/j.1474-919X.2001.tb04479.x

Irwin, R. E., Bronstein, J. L., Manson, J. S., and Richardson, L. (2010). Nectar robbing: ecological and evolutionary perspectives. Annu. Rev. Ecol. Evol. Syst. 41, 271-292. doi: 10.1146/annurev.ecolsys.110308.120330

Laiolo, P., and Jovani, R. (2007). The emergence of animal culture conservation. Trends Ecol. Evol. 22, 5. doi: 10.1016/j.tree.2006.10.007

Laman, T., and Scholes, E. (2012). Birds of Paradise: Revealing the World's Most Extraordinary Birds. Hanover, PA: National Geographic.

Lévêque, C., and Mounolou, J.-C. (2003). Biodiversity. Chichester: John Wiley and sons.

Levitis, D. A., Lidicker, W. Z., and Freund, G. (2009). Behavioural biologists do not agree on what constitutes behaviour. Anim. Behav. 78, 103-110. doi: 10.1016/j.anbehav.2009.03.018

MacDonald, D. W. (2013). "From ethology to biodiversity: case studies of wildlife conservation," in Quo Vadis, Behavioural Biology? Past, Present, and Future of an Evolving Science. Nova Acta Leopoldina, eds A. Wessel, R. Menzel, and G. Tembrock (Stuttgart: Deutsche Akademie der Naturforscher Leopoldina), 111-156.

Maclaurin, J., and Sterelny, K. (2008). What is Biodiversity?. Chicago, IL; London: The University of Chicago Press.

Magurran, A. E. (1988). Ecological Diversity and Its Measurement. Princeton, NJ: Princeton University Press.
Mendelson, T. C., and Shaw, K. L. (2005). Rapid speciation in an arthropod. Nature 433, 375-376. doi: 10.1038/433375a

Moore, J. A., Bell, B. D., and Linklater, W. L. (2008). The debate on behavior in conservation: New Zealand integrates theory with practice. Bioscience 58, 454-459. doi: 10.1641/B580513

Nei, M. (1986). Definition and estimation of fixation indexes. Evolution 40, 643-645.

Nogales, M., Martin, A., Tershy, B. R., Donlan, C. J., Veitch, D., Puerta, N., et al. (2004). A review of feral cat eradication on islands. Conserv. Biol. 18, 310-319. doi: 10.1111/j.1523-1739.2004.00442.x

Pearce, J. M. (2008). Animal Learning and Cognition: An Introduction, 3rd Edn. Hove: Psychology Press. Available online at: http://www.psypress.com/animal-learning-and-cognition

Pérez-Méndez, N., Jordano, P., García, C., and Valido, A. (2016). The signatures of Anthropocene defaunation: cascading effects of the seed dispersal collapse. Sci. Rep. 6:24820. doi: 10.1038/srep24820

Petchey, O. L., and Gaston, K. J. (2002). Functional diversity (FD), species richness and community composition. Ecol. Lett. 5, 402-411. doi: 10.1046/j.1461-0248.2002.00339.x

Podani, J., and Schmera, D. (1998). On dendrogram-based measures of funtional divesity. Oikos 115, 179-185. doi: 10.1111/j.2006.0030-1299. 15048.x

Priddel, D., Carlile, N., Humphrey, M., Fellenberg, S., and Hiscox, D. (2003). Rediscovery of the "extinct" Lord Howe Island stickinsect (Dryococelus australis (Montrouzier)) (Phasmatodea) and recommendations for its conservation. Biodivers. Conserv. 12, 1391-1403. doi: 10.1023/A:1023625710011

Roberge, J. M., and Aangelstam, P. (2004). Usefulness of the umbrella species concept as a conservation tool. Conserv. Biol. 18, 76-85. doi: 10.1111/j.1523-1739.2004.00450.x

Rubenstein, D. (2016). "Anthropogenic impacts on behavior: the pros and cons of plasticity," in Conservation Behavior, eds O. Berger-Tal and D. Saltz (Cambridge: Cambridge University Press), 121-146.

Ryan, S. J. (2006). The role of culture in conservation planning for small or endangered populations. Conserv. Biol. 20, 1321-1324. doi: 10.1111/j.1523-1739.2006.00347.x

Schleidt, W. M., Yakalis, G., Donnelly, M., and McGarry, J. (1984). A proposal for a standard ethogram, exemplified by an ethogram of the Bluebreasted Quail (Coturnix chinensis). Z. Tierpsychol. 64, 193-220. doi: 10.1111/j.1439-0310.1984.tb00360.x

Schwartz, M. W., Brigham, C. A., Hoeksema, J. D., Lyons, K. G., Mills, M. H., and Van Mantgem, P. J. (2000). Linking biodiversity to ecosystem function: implications for conservation ecology. Oecologia 122, 297-305. doi: $10.1007 / \mathrm{s} 004420050035$

Sirot, L. K., Brockmann, H. J., Marnis, C., Muschett, G., Marinis, C., and Muschett, G. (2003). Maintenance of a female-limited polymorphism in Ischnura ramburi (Zygoptera: Coenagrionidae). Anim. Behav. 66, 763-775. doi: 10.1006/anbe.2003.2279

Stone, P. A., Snell, H. L., and Snell, H. M. (2012). Behavioral diversity as biological diversity: introduced cats and lava lizard wariness. Conserv. Biol. 8, 569-573. doi: 10.1046/j.1523-1739.1994.08020569.x

Takacs, D. (1996). The Idea of Biodiversity. Philosophies of Paradise. Baltimore, MD; London: The Johns Hopkins University Press.

Tilman, D., Isbell, F., and Cowles, J. M. (2014). Biodiversity and ecosystem functioning. Annu. Rev. Ecol. Evol. Syst. 45, 471-493. doi: 10.1146/annurev-ecolsys-120213-091917

Valiente-Banuet, A., Aizen, M. A., Alcántara, J. M., Arroyo, J., Cocucci, A., Galetti, M., et al. (2015). Beyond species loss: the extinction of ecological interactions in a changing world. Funct. Ecol. 29, 299-307. doi: 10.1111/1365-2435. 12356

Van Dyke, F. (2008). Conservation Biology. Foundations, Concepts, Applications. Dordrecht: Springer.

van Loon., L. C. (2016). The intelligent behavior of plants. Trends Plant Sci. 21, 286-294. doi: 10.1016/j.tplants.2015.11.009

Vargas, A., Biggins, D., and Miller, B. (1999). Etología aplicada al manejo de especies amenazadas: el caso del turón de patas negras (Mustela nigripes). Etología 7, 33-39. 
Velo-Antón, G., and Cordero-Rivera, A. (2011). Predation by invasive mammals on an insular viviparous population of Salamandra salamandra. Herpetol. Notes 4, 299-301.

Whittaker, R. H. (1972). Evolution and measurement of species diversity. Taxon 21, 213-251. doi: $10.2307 / 1218190$

Wilson, E. O., and Peter, F. M. (1988). Biodiversity. Washington, DC: National Academy Press.

Wolf, M., and Weissing, F. J. (2012). Animal personalities: consequences for ecology and evolution. Trends Ecol. Evol. 27, 452-461. doi: 10.1016/j.tree.2012.05.001
Conflict of Interest Statement: The author declares that the research was conducted in the absence of any commercial or financial relationships that could be construed as a potential conflict of interest.

Copyright (c) 2017 Cordero-Rivera. This is an open-access article distributed under the terms of the Creative Commons Attribution License (CC BY). The use, distribution or reproduction in other forums is permitted, provided the original author(s) or licensor are credited and that the original publication in this journal is cited, in accordance with accepted academic practice. No use, distribution or reproduction is permitted which does not comply with these terms. 